\title{
EEN STUDIE OVER EEN LEIDER IN ACTIE I
}

\section{door H. Reinoud}

$\S 1$. Vanaf de opkomst van de "Scientific Management" beweging in het laatst van de vorige eeuw tot aan de tweede wereldoorlog hebben de vraagstukken met betrekking tot het leiding geven in bedrijven zich in feite sterk geconcentreerd op het organisatorisch aspect van de bedrijfsleiding. Van de verschillende functies, die ten aanzien van het leiding geven zijn te onderkennen, is het vooral die, welke betrekking heeft op de constructie van het mechanisme van handelingen en middelen, waarnaar in hoofdzaak de aandacht is uitgegaan.

De studie van de wetenschappelijke bedrijfsleiding was daarom feitelijk overwegend een studie van de wetenschappelijke bedrijfsorganisatie en het is misschien mede om die reden, dat hier te lande de uitdrukking „,scientific management" aanvankelijk met ",wetenschappelijke bedrijfsorganisatie" werd vertaald 1 ).

De bovenbedoelde periode zou men globaal in twee tijdperken kunnen verdelen; een eerste van $\pm 1880-1920$, een tweede van $1920-1940 /$ 1945.

In de eerste periode lag het accent overwegend op de organisatieproblematiek; elementaire tijd- en bewegingsstudie, de systemen van arbeidsbeloning, plannen en wegbepalen, de organisatiestructuur en onderdelen van de administratieve organisatie. Andere aspecten van het leiding geven werden zeker niet geheel voorbij gegaan. Taylor bijv. vroeg aandacht voor een doelmatige selectie van de arbeiders ${ }^{2}$ ), voor de grote betekenis van samenwerking tussen leiders en geleiden en voor de noodzaak van een "mental revolution" bij beiden 3). Maar in het geheel van de "Scientific Management" beweging hadden deze onderwerpen aanvankelijk toch beperkte betekenis.

In de tweede periode van de ontwikkeling van de wetenschappelijke bedrijfsleiding trokken ook de andere aspecten van het leiding geven in toenemende mate de belangstelling ${ }^{4}$ ). Men kan zich, die periode overziend, evenwel niet aan de indruk onttrekken, dat deze belangstelling - met uitzondering misschien van die ten aanzien van de marktanalyse tot een kleine groep voortrekkers bepaald bleef en dat in bredere kring en vooral in de practijk voor alles de organisatievraagstukken, die overigens een niet onbelangrijke verdieping ondergingen 5 ), primair de aandacht behielden.

1) Het vraagstuk van de terminologie is vrij gecompliceerd. Zie Hugo von Haan: "Rationalisierung als Weltbewegung im Spiegel ihrer Begriffslehre" (Zürich 1949). Wanneer ik op blz. 28 en 29 van dit geschrift o.a. lees: „Das Wort "Administration" als Synonym für management und organisation hat sich aber auch besonders in Holland Geltung errungen", en daarbij in dat verband het vroeger bestaande tijdschrift „Administratieve Arbeid" vermeld vind, twijfel ik er overigens aan of von Haan - secretaris-generaal van het Comité International de l'Organisation Scientifique ten aanzien van deze materie wel in alle opzichten een betrouwbare gids is.

2) $Z_{\mathrm{ijn}}$ systeem van arbeidsbeloning hield daarmede verband.

3) Zie o.a. L. Urwick and E. F. L. Brech: "The Making of Scientific Management", Volume I, Thirteen Pioneers (London 1951), in het bijzonder het laatste hoofdstuk: "The evolution of an idea".

4) De bekende Human Relation series onder redactie van Henry C. Metcalf leggen daar bijv, getuigenis van af.

5) Men denke o.a. aan de bedrijfsbegroting en de organisatiestructurur. Hier te lande is, zoals bekend, ook op dit gebied het werk van Prof. Dr Th. Limperg van betekenis geweest. 
$\S 2$. De aandacht voor organisatievraagstukken is na de laatste wereldoorlog zeker niet verminderd. In ons land begint men eigenlijk eerst sedert dien in wat ruimere kring inzicht te krijgen in de betekenis van de organisatiedeskundigheid voor productiviteit en efficiency ${ }^{6}$ ).

Internationaal gezien wordt het gebied, waartoe de organisatiearbeid zich uitstrekt, bovendien nog breder: organisatie van de topleiding en tijdsbesteding van de topfunctionarissen als min of meer afzonderlijk gebied van onderzoek, organisatie van de research, organisatie van de verkoop, e.d..

Daarnevens zijn er, ten dele als voortzetting van de aandachtsverbreding, die reeds in de periode 1920-1940/1945 inzette, thans enige andere facetten van het leiding geven in de belangstellingssfeer gekomen. Het zijn vooral de functies van de bedrijfsleiding met betrekking tot de bedrijfspsychologische en bedrijfssociologische verschijnselen in de bedrijfshuishouding, mede in hun verband met productiviteit en efficiency, die daarbij op de voorgrond staan of beginnen te komen.

Het is moeilijk het kenobject van de bedrijfssociologie en de bedrijfspsychologie zo te definiëren, dat duidelijk overeenkomst en verschil in het oog springen. Beide deelwetenschappen houden zich bezig met de verschijnselen, die betrekking hebben op de gevoelens, houdingen en gedragingen van de individuele mens en van groepen in hun onderlinge samenhang. De bedrijfspsychologie omvat bovendien de selectievraagstukken, in ons land aanvankelijk veelal aangeduid met psychotechniek, thans ook met psycho-diagnostiek 7 ). Voorzover beide wetenschappen zich bezighouden met groepsverschijnselen kan men een onderscheid zien in deze zin, dat de bedrijfspsychologie meer het accent op het individu en het individuele legt, de bedrijfssociologie op de groep, in het bijzonder op de groepsvormen en de groepsnormen. Voorzover het betreft de groepsverschijnselen wordt de bedrijfspsychologie ook wel gezien als een onderdeel van de sociale psychologie 8 ).

Ook de namen industriële psychologie en -sociologie, bedrijfssocio-

6) Men moet van het practisch effect te dien aanzien op korte termijn echter geen te hoge verwachtingen hebben. Het aantal algemene organisatiedeskundigen van enige betekenis is in ons land nog gering, terwijl een goede en actieve instelling van bedrijfsleiders ten aanzien van de organisatievraagstukken in hun dagelijkse arbeid een lange aanloopperiode zal blijken te vragen.

Het C.O.P., het N.I.V.E., de Nederlandse Maatschappij voor Nijverheid en Handel, het Centraal Sociaal Werkgevers Verbond, e.a. kunnen te dien aanzien goede diensten bewijzen.

Een bijzondere functie kan ook in dit opzicht het in 1953 gestichte Nederlands Studiecentrum voor Doelmatige Bedrijfsleiding vervullen.

7) Enige opmerkingen over de ontwikkeling van de bedrijfspsychologie vindt men o.a. in de intreereden van H. W. Ouweleen: "Het begrip participatie in de bedrijfspsychologie" (1950) en "De verhouding tussen bedrijfsorganisatie en bedrijfspsychologie" (1954).

Over de ontwikkeling van de bedrijfssociologie komt een interessante beschouwing voor in het tijdschrift "Mens en Maatschappij", Januari 1953, van de hand van Prof. Dr F. van Heek: "Twee richtingen in de bedrijfssociologie". Voorts komen in het Jaarboek 1953 van de Ned. Sociologische Vereniging inleidingen over de bedrijfssociologie voor van Prof. Dr A. Oldendorff en $\mathrm{Dr}$ D. Horringa met daarop gevolgde discussie.

8) Een uiteenzetting van het kenobject van de sociale psychologie vindt men in "Grondslagen der sociale psychologie" (1953) van Prof. Dr A. M. J. Chorus, Hoofdstuk I: Voorwerp en taak der sociale psychologie.

9) Zie bijv. F. van Dooren: „Aspecten van de industriële sociale psychologie” (1954) en Dr G. Kuiper: .Terreinverkenning voor het sociografisch onderzoek naar de sociale afstand tussen leiders en leden" (Intreerede 1954). 
logie, e.d. komen voor $\left.{ }^{9}\right)$. Er is op dit gebied weinig eenheid van terminologie 10 ).

In verband met evenbedoelde aspecten van het bedrijfsgebeuren worden allerlei namen en begrippen gebruikt, zoals human factor, human relations, industrial relations, group dynamics, feelings, attitudes, behaviour, satisfaction, social inter-action en/of in onze taal de menselijke fac tor, intermenselijke betrekkingen, gevoelens, houding, gedrag, bevrediging of satisfactie, arbeidsvreugde, arbeidsonlust, geestelijke gedraineerde arbeid, communicatie, informele organisatie, groepsdynamica, sociatrie, sociale paedagogie, enz..

§3. De begrippen bedrijfspsychologie of -sociologie mogen in de eerste periode van de ontwikkeling van de "Scientific Management" beweging onbekend zijn geweest, de begrippen human factor, human relations, e.d. waren het zeker niet. In de door C. B. Thompson in 1914 verzamelde artikelen over ."The Taylor system of industrial organization, to which the name "Scientific Management" has been applied" komt een ",bibliography of scientific management" voor, waarin ruim zestig artikelen worden vermeld over de ",personal factor in scientific management", de ",relation of scientific management to social problems" en „scientific management and organized labor".

Het bekende boek van Drury: ,Scientific Management, A history and criticism", dat in 1915 verscheen, bevat een tweetal hoofdstukken over de betreffende onderwerpen onder de titels "Scientific management as a solution of the labor problem" en "The human side". Alleen reeds uit deze twee feiten blijkt, dat de "Scientific Management" beweging al in zijn eerste ontwikkelingsphase met wat men thans noemt ,de menselijke factor" in de bedrijfshuishouding werd geconfronteerd.

Het kon ook moeilijk anders of de eerste organisatieadviseurs kregen al werkende in de practijk met deze problematiek te maken. Want bij het ontwerpen van hun systemen en methodieken mogen zij bewust of onbewust van de mens als "handelingenapparaat" zijn uitgegaan, in de practijk moesten zij wel op de mens als geestelijk, psychisch en sociaal wezen stuiten.

Het verschijnsel van de zgn. informele organisatie in de vorm van het verzet van de "groep" tegen productienormen en tarieven bijv. namen zij al spoedig zeer concreet waar. Wat de voortrekkers in het brede terrein van de doelmatige bedrijfsleiding evenwel ontbrak, was inzicht en doorzicht in de betreffende vraagstukken, waardoor $z$ ij lang vast bleven houden aan te eenvoudige speculaties over de drijfveren van de mens met betrekking tot zijn werk.

$\mathrm{B}_{\mathrm{ij}}$ de beoordeling hiervan mogen evenwel twee feiten niet uit het oog worden verloren. Allereerst was kennis van de gecompliceerdheid van bedoelde problematiek in het algemeen vreemd aan hun tijd.

.Profits, maximum production, autocratic control - what other goals could there then be?" merkt Drury in dit verband op.

En ten tweede de wetenschap, dat er ten aanzien van de menselijke factor in het bedrijf een eigen problematiek was en dat het noodzakelijk

10) $\operatorname{Dr}$ A. de Jong zoekt in zijn studie ,De menselijke factor in de bedrijfshuishouding en de bedrijfseconomische problematiek" (1954), blz. 28, een oplossing in het gebruik van het woord "bedrijfspsycho-sociologie".

Van Dooren "gebruikt in de aan zijn dissertatie toegevoegde stellingen ook het woord "psycho-sociologie". 
was dat die voorwerp van aparte studie werd, was reeds tegen het einde van de eerste periode aanwezig. Zoals blijkt uit de uitspraak van Taylor zelf: ,There is another type of scientific investigation which has been referred to several times in this paper, and which should receive special attention, namely, the accurate study of the motives which influence men" 11).

Men kan niet zeggen dat die studie in de tweede periode van de ontwikkeling van de "Scientific Management" beweging direct welbewust de volle aandacht kreeg. Eerst de verrassende en onverwachte resultaten van het Hawthorne onderzoek - begonnen als een onderzoek naar de invloed van de physieke werkomstandigheden op de productiviteit en efficiency - heeft daartoe een krachtige impuls gegeven ${ }^{12}$ ).

$\S 4$. Alvorens mijn beschouwing te vervolgen lijkt het mij nuttig ter voorkoming van misverstand een korte opmerking te maken over het begrip ,organiseren".

Zoals ik reeds in $\S 1$ deed uitkomen, onderscheid ik organiseren van leiden en leiding geven. Organiseren is de arbeid, welke betrekking heeft op de doelmatige ordening van handelingen en middelen in het bedrijf.

De "handelingen" kunnen zowel de menselijke als de machinale handelingen betreffen, de "middelen" zowel de actieve als de passieve productiemiddelen.

Wat de menselijke handelingen betreft wordt de mens niet zonder meer als een ,,handelingenapparaat" gezien. Rekening wordt o.a. gehouden met de psychische en physieke mogelijkheden van de mens en met de gevoelens, houdingen en gedragingen van de mens en van groepen. De studie van deze laatste verschijnselen behoort echter niet tot de organisatiewetenschap, maar tot de bedrijfspsychologie en de bedrijfssociologie.

De organisatiedeskundige moet echter om minstens drie redenen enige kennis van en enig inzicht in de bedrijfssociologie en -psychologie bezitten en van hun normatieve aanbevelingen op de hoogte zijn 13).

Ten eerste om er bij zijn constructie-arbeid rekening mede te houden: ten tweede om bij zijn onderzoek in een bedrijf aan te voelen of er op het gebied, dat de bedrijfspsychologie en -sociologie bestrijken, vermoedelijk zodanige problemen liggen, dat er aanleiding is de bedrijfsleiding te adviseren een psycholoog en/of socioloog te raadplegen; ten derde om in die gevallen, dat het niet mogelijk is of waarin het vanwege de beperktheid van de problemen niet wenselijk lijkt een psycholoog of socioloog te raadplegen, zelf enige raad te kunnen schaffen.

In het laatste geval uiteraard met bijzondere bedachtzaamheid.

De definities van organiseren en organisatie, die psychologen, sociologen, e.d. hanteren, wijken veelal af van die, welke ik hierboven heb ver-

11) „Principles of Scientific Management", druk 1947, blz. 119.

12) Zie o.a. de reeds vermelde beschouwing van Prof. van Heek en voorts Prof. Dr H. J. van der Schroeff: ,Rationalisme en sentiment in de organisatie in het licht van het Hawthorne onderzoek", Tijdschrift voor Efficientie en Documentatie, December 1952.

13) $\mathrm{Zie}$ in dit verband o.a. Prof. H. W. Ouweleen: „De verhouding tussen bedrijfsorganisatie en bedrijfspsychologie" (oratie 1954). Voorts, in ten dele ander verband. het reeds vermelde boek van Dr A. de Jong.

De verwijzing naar deze beide nuttige publicaties wil overigens niet zeggen, dat ik mij met de inhoud ervan geheel verenig. 
meld. Eerstgenoemden beperken hun begrip organiseren meestal tot de menselijke handelingen en betrekkingen. Daardoor vallen bijv. onderwerpen als plannen, ruimtelijke indeling, e.d. buiten hun definitie 14).

$\S 5$. De organisatiewetenschap is thans ongeveer 60 jaar oud, $z \mathrm{ij}$ is dus een nog jonge wetenschap en vertoont daarvan de sporen. De wetenschappen met betrekking tot de intermenselijke betrekkingen in het bedrijf verkeren echter bij haar vergeleken nog in de kinderschoenen 15), al zijn hun moederwetenschappen, de psychologie en de sociologie, al meer op leeftijd.

Moeten de resultaten derhalve met de nodige omzichtigheid worden beoordeeld en gehanteerd, vast staat, dat bedoelde wetenschappen in die korte tijd reeds bijdragen van betekenis hebben kunnen leveren ter verbetering van het leiding geven, c.q. van de werkomstandigheden in bedrijven. In de U.S.A. is het aantal onderzoekingen, dat op de betreffende materie betrekking heeft, zowel als het aantal onderzoekers, instituten en bureaux, dat zich met deze onderzoekingen bezighoudt, nauwelijks meer te overzien. Ook in ons land hebben sinds de bevrijding enige onderzoeken van deze aard plaatsgevonden 16 ); in het bijzonder wordt thans een aantal omvangrijke studies - gefinancierd met overheidsgelden - ondernomen èn om de resultaten èn om deskundigen op dit gebied te vormen ${ }^{17}$ ).

$\S 6$. Voor leiders en organisatiedeskundigen kan het dus van nut zijn kennis te nemen van de resultaten en normatieve aanbevelingen. waartoe de betreffende deskundigen zijn gekomen en in de toekomst zullen komen. Voor leiders om hun wijze van leiding geven en daarmede de efficiency van hun bedrijf te verbeteren, voor organisatiedeskundigen om de redenen uiteengezet in $\$ 4$.

Er is echter nog een belangrijk punt waarom het van bijzonder belang is voor de theoretische en practische beoefenaren van de organi-

14) Van Doorne (zie noot 9 op blz. 475) hanteert een omschrijving van organisatic, die aansluit bij de door mij gegevene: „De ordening van werkende mensen, werktuigen, werkruimte en te bewerken materiaal, met het oog op het doel van het bedrijf, is een ordening, die wij organisatie noemen." Onderwerp van zijn studie zijn de mensen in deze definitie, maar dan in een bepaald aspect: ..Het zijn vooral de mensen in het bedrijE, waarop wij ons in deze beschouwing zullen richten en dit niet zozeer naar hun werkzaam zijn en prestaties leveren als individuele personen, maal meer naar hun beïnvloed worden door, en hun ervaren van de relaties met andere bedrijfsleden, welke relaties voortvloeien uit het samen georganiseerd zijn, het samen werken en het dientengevolge samen zijn (Blz. 13).

1.) In zijn rapport "The impact of budgets on people", opgesteld ten behoeve van het Controllers Institute of America, merkt Chr. Argyris op:

"Perhaps one of the most important developments which has occurred in the industrial world during the past decade (cursivering van mij) has been the great emphasis upon, and interest in, human relations."

16) Zie o.a. Dr Ir M. G. IJdo: "Plezier in het werk";

Dr A. M. Kuylaars S.J.: ..Werk en leven van de industriële loonarbeider, als object van een sociale ondernemingspolitiek";

Dr H. A. Hutte: "Op zoek naar het gelaat der arbeidsgroep" in Mens en Onderneming. IVe jaargang, AfI. 5, December 1950, ,Het groepsinterview als methode van onderzoek inzake arbeidsconflicten" in Mens en Onderneming. IVe jaargang. Afl. 4. en De Naamlooze Vennootschap, Jrg 29 no 11 (Febr. 1952):

"Experiences in studying social psychological structures in industry", Human Relations, Vol. II, $\mathrm{Nr}$ 2, London and Ann Arbor (April 1949).

17) Prof. Dr J. Koekebakker: "Sociaal-psychologisch onderzoek in het bedrijfsleven" in Economisch-Statistische Berichten dd. 22 December 1954. 
satiewetenschap c.q. de bedrijfseconomie goed kennis te nemen van de ontwikkeling van de bedrijfssociologie en -psychologie.

Verschillende onderzoekers op laatstgenoemde gebieden beginnen $\mathrm{nl}$. op grond van de resultaten van hun onderzoeken critische opmerkingen te maken over de basisbeginselen van de organisatieleer. De vergaande arbeidsverdeling en het beginsel van eenheid bijv. worden opnieuw, vanuit hun gezichtspunt bezien, op critische wijze in beschouwing genomen.

Het verband tussen bedoelde wetenschappen komt aldus in een bijzonder licht te staan. Ouweleen formuleert dit verband aldus, dat „in de toekomst een wetenschapsgebied met als object de samenhang tussen enerzijds de organisatiestructuur en de organisatietechnieken en anderzijds de wereld van de instelling en de onderlinge verhoudingen van de mensen zal ontstaan" 18).

§ 7. De in het voorgaande aangeduide problematiek is bedoeld als een inleiding voor een wat uitvoerige en commentariërende bespreking van een m.i. belangrijke Amerikaanse studie, die door Chr. Argyris is gepubliceerd onder de titel .Executive Leadership" met als ondertitel "An Appraisal of a Manager in Action". Het is een publicatie, in 1953 uitgegeven onder auspiciën van het Yale Labor and Management Center. Enige nadere mededelingen over dit centrum en de schrijver, zoals die uit deze en enige andere publicaties blijken, volgen hieronder.

Het Yale Labor and Management Center ontstond in 1937 en kreeg zijn formele status in 1944 . Het wil een theoretisch raamwerk construeren, dat dienen kan voor de verklaring van individueel- en groepsgedrag ,in the context of organizations".

In een van de laatste publicaties wordt de ,basic purpose" als volgt omschreven: ,to contribute to the building of a theoretical framework for the study, understanding, prediction and regulating of human behaviour in organizational situations, whatever their area (i.e. economic, political, educational, social, community, etc.)" 19 ).

Het wil dit doel ook in het bijzonder realiseren door onderzoek in bedrijven.

Algemeen Directeur van het centrum is $\mathrm{E}$. Wight Bakke, wiens in 1950 verschenen boek „Bonds of Organization", gebaseerd op een in 1947 ingesteld onderzoek dat ten doel had ,describing, analyzing and evaluating the structure and dynamics of human relations in the Southern New England Telephone Company and in the Connecticut Union of Telephone Workers", ook in ons land niet geheel onbekend is.

Het centrum heeft in de betrekkelijk korte periode van zijn bestaan zeventien boeken en interimrapporten gepubliceerd, voor een groot deel betrekking hebbend op vraagstukken in bedrijfshuishoudingen.

18) Intreerede 1954. Zijn mening, dat ,noch uit bedrijfsorganisatorische, noch uit de sociologische, psychiatrische of psychologische theorie de maatregelen af te leiden zijn. die genomen moeten worden om de groei van het bedrijf in de richting van het algemene bedrijfsdoel zo goed mogelijk te bevorderen". lijkt mij voor de practijk te strak geformuleerd. Wel kan ik mij verenigen met zijn toevoeging "Wat nodig is, is in de eerste plaats een uitbreiding van onze kennis omtrent de samenhang van deze verschillende aspecten."

19) Het feit, dat het centrum naar een theoretisch fundament streeft, heeft niet nagelaten de argwaan van de aanhangers van ."case studies" te wekken, die, naar Wight Bakke meedeelt, hun afkeuring hebben laten blijken door het centrum en zijn medewerkers als „system builders" te etiketteren. Terecht merkt Bakke op, dat tussen theorie en practijk geen kloof gaapt: ..We have steadily contented however that sound theory is the most practical thing in the world." 
Het centrum is de eerste phase van zijn arbeid thans geëindigd met de opstelling van een voorlopig ",framework" (overigens, naar Bakke schrijft, nog "far from perfect"). Het ziet nu zijn tweede phase in de nadere toetsing van zijn theorie door middel van een groot aantal onderzoeken in onderscheidene bedrijven. Een eerste onderzoek is gereed gekomen en de resultaten daarvan zijn samengevat in het eerste nummer van een nieuwe reeks publicaties "Studies in Organizational Behavior, No. 1, Organization of a Bank", door Chr. Argyris, 1954, waaraan enige van bovenstaande opmerkingen zijn ontleend.

De schrijver van het boek „Executive Leadership”, Chr. Argyris, is een van de "directors of research projects" van het Labor and Management Center Yale University.

Uit het boek blijkt niet hoe Argyris zijn beroep precies aanduidt. $\mathrm{H}_{i j}$ beschouwt zich niet als professioneel psycholoog. Ergens in het boek over zichzelf schrijvend, spreekt hij van ,other scientists in human relations"; in de laatste publicatie van het Yale Center, het hierboven reeds vermelde ,.Organization of a Bank", schrijft Bakke: „Dr Argyris with his background of training in psychology, sociology and business administration", enz.. Argyris heeft verschillende publicaties op zijn naam staan. Enige jaren geleden is hij belast geweest met een onderzoek naar "The present state of research in human relations in industry" (in de U.S.A.), waaromtrent door hem een rapport is uitgebracht; thans vertoeft hij enige tijd in Europa.

$\S 8$. Het boek "Executive Leadership" is niet in de eerste plaats bedoeld voor vakgenoten van de schrijver. Integendeel, de schrijver richt zich zeer nadrukkelijk tot leiders in de uitvoerende sector van het bedrijfsleven, wier aandacht hij vraagt voor zijn onderzoek en de resultaten daarvan. "This book is written in a non-academic style and is primarily directed at the many practicing executives", aldus begint Argyris zijn voorwoord en het derde deel van zijn boek draagt het opschrift "Lessons for leaders".

Kan het om die reden ook voor leidinggevende functionarissen in ons land van betekenis zijn om kennis te nemen van de resultaten van het onderzoek (en de interpretatie daarvan), ook voor de beoefenaren van de organisatiewetenschap lijkt het mij om de hierboven uiteengezette redenen van belang een en ander te vernemen over de door Argyris ondernomen studie en de verkregen resultaten.

Daarbij komt in dit geval, dat de schrijver - evenals waarschijnlijk het gehele Yale Labor and Management Center - zich in het bijzonder richt op het verband tussen de wijze van leiding geven en de beginselen van de organisatieleer. ,I believe that we will begin to obtain insights into executive leadership if we study it concretely in its full complexity and always in relation to the type of organization within which it exists" 20 ).

In het bijzonder ziet hij daarbij op een aantal beginselen, waarop de organisatiestructuur berust. Ik kom daarop nog nader uitvoeriger terug.

Er zijn in de loop der tijden wel meer verhandelingen geschreven over de eisen, die aan het leiding geven moeten worden gesteld. Deze hadden

20) Hierbij moet worden opgemerkt, dat de schrijver het woord ,organization" soms dooreen gebruikt voor bedrijf en organisatie. In het zoeven vermelde verband bedoelt hij het woord "organization" echter vooral in de betekenis van organiseren en organisatie als vermeld in de aanhef van $\S 4$. 
evenwel meestal betrekking op een omschrijving van de eisen, die aan de persoonlijkheid van een leider moeten worden gesteld en waren m.i. slechts van betrekkelijke waarde ${ }^{21}$ ).

Argyris daarentegen volgt een geheel andere weg. $Z_{i j n}$ boek, berustend op een zeer langdurige, waarschijnlijk dagelijkse waarneming van een leider in actie, beschrijft en analyseert diens gedrag ten aanzien van de onder hem werkende "supervisors", hoe dat gedrag het dagelijks leven van hemzelf en zijn "supervisors" beinvloedt, hoe de groep supervisors als groep formeel en informeel reageert, welk het verband is met de organisatiestructuur en efficiency, welke de verborgen kosten van dit soort leiderschap zijn. Het onderzoek heeft dus eveneens een ander karakter dan de onderzoekingen naar de wijze waarop directeuren hun tijd besteden, zoals beschreven door de Zweed Sune Carlson in zijn boek .Executive Behavior" (Stockholm 1951) en hier te lande door Mr H. Luyk in zijn boekje „Waar blijft de tijd van de directeur?" (1952).

$\S 9$. Voor een goed inzicht in het onderzoek en de critische beoordeling van de resultaten kan het nuttig zijn eerst een aantal feitelijke gegevens te vermelden; op een aantal van deze gegevens wordt later teruggekomen.

Het onderzoek vond plaats in een industrieel bedrijf, dat onderdeel is van een grote onderneming, die is gevestigd in een stad met ongeveer 100000 inwoners. Het betreffende bedrijfsonderdeel ondervindt felle concurrentie van andere bedrijven ter plaatse en in het land. Er wordt bijna geheel op bestelling gewerkt (custom made), waarschijnlijk in betrekkelijk kleine series. De productie-,.planning" en -,,control" worden door de schrijver als moeilijk angeduid. De arbeiders zijn overwegend semi-geschoold en geschoold en voor een belangrijk deel reeds enige jaren in het bedrijf werkzaam. $Z_{i j}$ ontvangen hoge lonen en andere renumeraties. Het bedrijf heeft ongeveer 600 arbeiders in dienst. Onder de .leider" van het bedrijfsonderdeel (hieronder nader aan te duiden met ,Leider") werken rechtstreeks 20 ,supervisors" 22); de meesten hunner zijn minstens acht jaar in dienst en hebben hun promotie in het bedrijf gemaakt. Van de supervisors behoren er 17 tot het middelbare leiding gevende niveau (middle management); de andere 3 hebben een iets belangrijker functie, maar worden door de grootte van de supervisors -groep en door de wijze van leiding geven door de Leider in feite als één groep behandeld. De meerderheid van de supervisors heeft minstens high school 23 ), sommigen zijn op een "college" geweest. De supervisors werken als groep zeer hard en ,, are highly motivated".

In het bedrijf spelen de vakbonden een grote rol (a unionized plant). vermoedelijk een grotere rol dan in ons land.

Het bedrijf was op het moment van de benoeming van de Leider sterk verliesgevend, maar is door hem in korte tijd rendabel gemaakt.

De voorganger van de Leider was een goedhartig man, tot wie ieder

21) Taylor bijv. noemde de volgende negen kwaliteiten, waaraan goede all round bazen in de fabriek zouden moeten voldoen: brains, education, special or technical knowledge and manual dexterity or strength, tact, energy, grit, honesty judgement or common sense, good health. Shop Management, 1911, blz. 96.

22) In verband met de omstandigheid, dat ik er niet zeker van ben of het woord "supervisor" in het onderhavige bedrijf in alle gevallen door het Nederlandse "baas" wordt gedekt, heb ik het onvertaald gelaten.

23) middelbare school tot $17-19$ jaar, gelijk bekend niet zonder meer te vergelijken met onze middelbare onderwijsinstellingen. 
in het bedrijf gemakkelijk toegang had. Daardoor en door andere redenen waren de chefsposities ondermijnd. Er was een toestand ontstaan, waarbij de supervisorsfunctie niet erg meer in trek was.

Het bedrijfsonderdeel beperkt zich tot de productie in engere zin. De verkoopafdeling en de kostprijsafdeling behoren er niet toe.

De supervisors wijten veel van hun problemen aan het planbureau en hebben weinig op met de ,kostprijsmensen"; de verkopers wordt verweten niets van de productie en de moeilijkheden van de supervisors te begrijpen.

De technieken, die bij het onderzoek worden gebruikt, zijn ,member centered conferences", ,research interviews" en ,observation". In een appendix wordt nog een beschouwing gewijd aan de betrouwbaarheid en accuratesse van de gebruikte technieken.

De Leider, wiens activiteiten voorwerp van onderzoek zijn, is èn in de ogen van de topleiding èn in die van zijn ondergeschikten een geslaagd leider. De topleiding vindt hem een prima man, misschien iets te "forceful". Hoe de arbeiders hem zien wordt niet nadrukkelijk vermeld, wel dat hij het goed met de vakverenigingen kan vinden.

Het onderzoek in het bedrijf maakt deel uit van een veel uitgebreider onderzoek, dat het gehele concern omvat, welk onderzoek onder leiding staat van de socioloog Prof. W. Whyte en waarschijnlijk nog steeds aan de gang is. De professoren Wight Bakke en Whyte hebben Argyris bij zijn onderzoek en publicatie bijgestaan.

Het is van belang in het oog te houden dat de Leider, èn beoordeeld naar de resultaten van het door hem geleide bedrijf èn naar de mening van zijn superieuren en ondergeschikten, in de categorie geslaagde leiders kan worden ingedeeld. De critische beschouwingen van de schrijver richten zich dus niet op een mislukt bedrijfsleider.

$\S 10$. De schrijver onderzoekt, gelijk reeds opgemerkt, de wijze waarop de Leider zijn supervisors leidt, zijn stijl, zijn methode, de regels, die hij bij zijn leiding geven volgt. Hij tracht daarbij - gegeven de bestaande organisatie - twee groepen van factoren uiteen te houden:

1. die welke betrekking hebben op de persoonlijkheid van de Leider;

2. die welke zijn beginselen, gebaseerd op de door hem opgedane ervaring, betreffen.

$\mathrm{H}_{\mathrm{ij}}$ tracht dat te doen, want, zoals hij zelf opmerkt, beide groepen factoren zijn uiteraard tot op zekere hoogte interdependent.

In grote lijnen is het boek als volgt gecomponeerd.

Eerst analyseert de onderzoeker op grond van zijn langdurig contact met de Leider en de supervisors diens wijze van leiding geven. Vervolgens geeft de Leider zelf zijn ",leadership pattern" weer. Daarna worden de gevolgen van zijn wijze van leiding geven op de supervisors beschreven, terwijl tenslotte enige normatieve aanbevelingen worden gegeven voor leiders.

Het boek is boeiend geschreven en bevat een groot aantal weergaven van de gesprekken tussen Leider en supervisors, tussen supervisors onderling, enz..

Bij de beoordeling van het onderzoek zal men er goed aan doen de positie van het bedrijf en van de Leider, zoals in $\$ 9$ omschreven, in het oog te houden.

Zoals daaruit blijkt is er sprake van de leider van een operationeel 
bedrijfsonderdeel, dus niet van de leider van een stafafdeling of van de president of een lid van de centrale leiding van het concern. Bovendien is de functie beperkt tot productie in engere zin (geen administratie bijv.).

$\S 11$. Allereerst geeft Argyris nu in een zevental karakteristika zijn analyse van het gedrag van de Leider.

11.1. Een van de kenmerken, die bij waarneming van de Leider direct in het oog valt, is zijn herhaaldelijk ingrijpen in het werk van zijn ondergeschikten. Hij is regelmatig "on the floor", geeft zijn supervisors aanwijzingen, tracht hun nieuwe ideeën ,in te pompen", vraagt op critische wijze inlichtingen over verspilling en andere ondoelmatigheden.

Nauwelijks is hij uit de fabriek terug op zijn kantoor of hij roept een of meer van $z$ ijn supervisors bij zich, meestal door middel van de luidsprekerinstallatie. Komen zij niet spoedig, dan gaat direct daarna de telefoon. Hij beslist zeer snel ter plaatse (making on-the-spot decisions), wat door zijn ondergeschikten hoog wordt gewaardeerd.

Een belangrijk punt is voorts, dat hij weinig met de supervisors als groep spreekt. Uit de weergegeven gesprekken blijkt, dat de supervisors, zodra de Leider een fout met hen bespreekt, elkaar de schuld geven. De supervisors treden agressief op tegen elkaar, een punt waarop later nog wordt teruggekomen.

11.2. Een tweede kenmerk is, dat de persoonlijke doeleinden, waardemaatstaven en gevoelens van de Leider in de eerste plaats op het bedrijf zijn gericht. Hij staat op en gaat naar bed met zijn bedrijf. Bij alle vragen en gesprekken legt hij de nadruk op het belang van en voor het bedrijf. Als in een gesprek met de supervisors het bekende verschijnsel van de informele restrictie van productie en tempo door een groep arbeiders ter sprake komt, zegt de Leider: ,.Je moet er met de groep op ingaan, laten zien dat dergelijke restricties niet fair zijn, dat het hun en ons bedrijf is, enz." 24 ).

Bijeenkomsten met het personeel moeten niet gaan over een fonteintje, dat ergens aangebracht moet worden, maar over ideeën over "ons" werk, hoe de productiekosten verminderd kunnen worden, enz..

Van zijn supervisors vraagt hij volstrekte loyaliteit tegenover het bedrijf, zoals hij zelf meer dan $100 \%$ loyaal is.

11.3. Een ander karakteristiek van de Leider is, dat het bedrijf en de organisatie deel uitmaken van zijn "self picture". Als iemand graag beveelt en in het centrum van de aandacht staat, kan een leidende positie die ",behoeften" veelal vergaand bevredigen. $\mathrm{Er}$ is, zoals Argyris het uitdrukt, een basisovereenkomst tussen de persoonlijke behoeften van de Leider en de eisen van het bedrijf. Het bedrijf wordt daardoor deel van hemzelf. Daarmede hangt samen, dat de Leider van zijn supervisors eist. dat ook zij krachtig bevelen en er voor zorgen in het centrum van de aandacht van hun ondergeschikten te komen. Hijzelf is gelukkig met deze houding en dit gedrag en meent daarom, dat de supervisors dat ook zullen zijn. Wie een andere conceptie van leiding geven heeft, bijv. minder bevelen, meer luisteren en raad geven, wordt becritiseerd en heeft ,iets te leren".

Wie zich gedraagt conform de Leider wordt geprezen. De Leider laat geen ruimte voor de mogelijkheid, dat een andere wijze van leiding geven even goed of beter kan zijn.

24) Uiteraard een onderschatting van de diepliggende motieven, die achter bepaalde aspecten van de informele organisatie liggen.

m a b blz. 483 
11.4. Een ander gewichtig punt is, dat de Leider zijn supervisors bijna altijd individueel behandelt, dus niet als groep. En als hij ze als groep bijeen heeft, houdt hij nog veelal een gesprek met een van hen. Het gevolg daarvan is, dat de supervisors zich weinig als een team voelen en ontwikkelen, sterk afhankelijk worden van de Leider (leader centered) en weinig zelfvertrouwen krijgen.

11.5. De Leider - en alleen hij - licht de supervisors in over komende gebeurtenissen in het bedrijf. Een van de vele kwaliteiten van de Leider is, dat hij er voor zorgt, dat de supervisors het nieuws over het bedrijf altijd horen vóór hun ondergeschikten. Het feit, dat de supervisors voor bedoelde informatie uitsluitend op de Leider aangewezen zijn, bevordert evenwel hun afhankelijkheid van de Leider.

11.6. Een verschijnsel, dat de Leider typeert, is voorts dat hij altijd het heden beklemtoont. Van toekomstplannen moet hij niets hebben, iedere dag heeft genoeg aan zijn eigen kwaad. Wat telt is het heden. De toekomst is voor de "denkers", voor de mensen met "lange haren", zoals de onderzoeker!

Door deze houding krijgen de supervisors weinig visie op de toekomst; elke dag kan een onaangename verrassing brengen. Gevoelens van onzekerheid worden daardoor bevorderd. Het gevolg is, dat de tendentie om tegen de Leider aan te leunen, zich tot hem om steun en informatie te wenden, versterkt wordt.

11.7. Tenslotte, de Leider stelt realistische taken. Het is zijn principe om bij taakstellingen niet te hoog te mikken, omdat er anders onnodig teleurstellingen voor de betrokkenen ontstaan, die lange tijd hun nadelige invloed doen gevoelen.

$E_{r}$ is tussen verschillende van deze kenmerken een verband. Wanneer een supervisor een onvoldoende graad van loyaliteit tegenover het bedrijf toont (11.2) of niet handelt overeenkomstig de opvattingen, die de Leider over zichzelf heeft (11.3), dan tracht hij hem op te voeden door versterkt ingrijpen (11.1).

De gevonden karakteristika kunnen nog tot zekere hoogte verdeeld worden naar die, verband houdende met de persoonlijkheid van de Leider $(11.1,11.2,11.3)$ en die, welke betrekking hebben op zijn in de loop der tijden als nuttig opgedane ervaring $(11.4,11.7)$. De beklemtoning van het heden kan men zien (11.6) als voortvloeiende èn uit de persoonlijkheid èn uit de ervaring van de Leider. In het beeld van de Leider, dat Argyris tot zover geeft, zal menigeen geheel of voor een groot deel overeenkomst zien met dat van tal van leiders, werkzaam op verschillende niveaux in een bedrijf. Het is echter in het bijzonder de anatomie van het beeld, zoals Argyris die laat zien, die reeds direct een eigen licht werpt op sommige problemen van het leiding geven.

$\S 12$. In vraagstukken, die betrekking hebben op de mens en op tussenmenselijke verhoudingen, is het vaak van groot belang om te weten hoe de persoonlijke gevoelens en inzichten zijn van degene die betrokken is bij een bepaald verschijnsel of een bepaalde situatie. Het gaat dan dus niet om de objectieve benadering van het verschijnsel of de situatie, maar om de subjectieve waardering door de betrokkene. De schrijver-onderzoeker geeft daarom uitvoerig weer hoe de Leider zelf zijn „leadership pattern" ziet. Ik moet hieronder volstaan met een zeer summiere uiteenzetting. 
Zoals hierboven vermeld, houdt iemands wijze van leiding geven verband, soms nauw verband, met zijn persoonlijkheid. De Leider evenwel meent, dat een chef zijn persoonlijkheid buiten zijn functie moet houden en dat hij dat ook inderdaad doet! De wijze van leiding geven wordt z.i. bepaald door zijn ondergeschikten 25); die zijn nu z.i. ,inhaerent lui" en het ontbreekt hun aan de vitaliteit, die hij zelf heeft. De Leider preciseert zijn gedrag nog als volgt.

12.1. Wat je ook gelooft, geloof daar krachtig in en verdedig je opvattingen taai. Maar eerlijkheid is daarbij geboden. Om eerlijk te zijn moet een leider

a. alle belangrijke feiten weten;

b. ze zorgvuldig wegen en eerst daarna zijn beslissing nemen.

En een goed leider weet altijd alle feiten.

12.2 De Leider ziet zichzelf als iemand met durf en als een harde werker, die altijd het werk gedaan weet te krijgen (ten behoeve van zijn chef en het bedrijf).

Om zijn taak te vervullen moet men met zijn werk opstaan en geen hobby's hebben.

Om het werk gedaan te krijgen zal men soms vijanden moeten maken. Dat is onvermijdelijk, maar een goed leider zorgt spoedig voor vrede.

Een bekwaam leider weet bij zijn ondergeschikten krachtig werkende motieven op te wekken om hard te werken (an effective leader arouses motivation through his action). Actie en loyaliteit spelen dus een belangrijke rol.

12.3. Een goed leider moet er regelmatig op bedacht zijn vooruit te komen. Niet alleen ter wille van het geld, hoewel geld niet onbelangrijk is. Om vooruit te komen moet men veel contacten leggen met allerlei personen en een goed leiderschap tonen.

12.4. Een leider moet zijn ondergeschikte leiders "dicht bij” zich houden. De supervisors moeten goed weten dat hun leider achter hen staat. Een goed leider weet, dat de supervisors de ,backbone of management" zijn. Uit het gesprek over dit punt, dat Argyris met de Leider heeft, blijkt, hoe de Leider zich in feite sterk afhankelijk voelt van zijn supervisors. Dit kan mede verklaren waarom hij zijn supervisors zo individueel behandelt. $Z_{i j}$ blijven dan op de Leider geconcentreerd en van hem afhankelijk.

12.5. Een kundig leider zorgt, dat de functies van de supervisors bijzonder gerespecteerd en begeerd worden. (The worse thing a management leader can do is to bypass his supervisors).

Bij deze uiteenzetting valt o.a. op hoe makkelijk de Leider spreekt over het verkrijgen en interpreteren van de feiten ${ }^{26}$ ) en hoe vlot hij denkt over vrede stichten na conflicten.

Behalve hoe hij zijn wijze van leiding geven ziet, geeft de Leider ook nog een uiteenzetting van het waarom.

Allereerst noemt hij de onvoldoende capaciteiten van de supervisors.

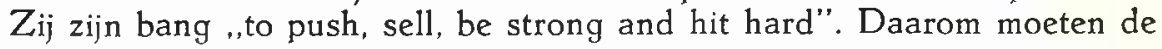

25) Deze uitspraak bevat ongetwijfeld een zekere waarheid. De wijze van leiding geven wordt in niet onbetekenende mate functioneel door de groep "ondergeschikten" bepaald, maar dan toch m.i. anders dan de Leider het ziet.

26) Het is bijv. vaak niet gemakkelijk op korte termijn een goed inzicht in de gevoelens van zijn ondergeschikten, die ook - en vaak belangrijke - feiten zijn, te verkrijgen. 
supervisors krachtig geleid worden. „I think the employees want a leader who is strong" (de sterke man theorie!).

Een tweede oorzaak is gelegen in de onvoldoende leiderscapaciteiten van zijn voorganger. Die was een vriendelijke, rustige gentleman. De supervisors hadden te weinig technische know how. Er waren geen ,,control systems", o.a. geen budget, voorraadadministratie, productiestaten, geen functie- en taakomschrijvingen, geen "standard operating procedures".

Als derde oorzaak noemt hij het feit, dat de employés (of een groot deel er van, dat is niet duidelijk vermeld) op tijdloon werken. Aangezien de geldelijke prikkel er niet is, moet de Leider dus zorgen voor andere krachtig werkende motieven. Dat verklaart z.i. mede waarom hij er ,zo boven op moet zitten".

Stellen wij nu naast elkaar de beschrijving van de wijze van leiding geven van de onderzoeker en die van de Leider dan blijkt het volgende.

Analyse van de onderzoeker.

$\mathrm{O}$, The Leader is constantly interacting and constantly commanding.

$\mathrm{O}_{2 .}$ The Leader's personal goals. values, and feelings are primarily organizationally centered.

$\mathrm{O}_{n}$ The Leader makes the organization a part of his self picture.

$\mathrm{O}_{4}$ The Leader handles the supervisors as individuals.

$\mathrm{O}_{\text {, }}$ The Leader controls the transmission of important information.

$\mathrm{O}_{6}$ : The Leader emphazises the present.

$\mathrm{O}_{7}$ The Leader sets realistic goals.

Niet ieder van de elementen van beider analyse is vergelijkbaar. Rekening houdende met de toelichting, die de Leider bij zijn analyse geeft. kan men zeggen dat $\mathrm{O}_{1}$ en $\mathrm{O}_{\text {, }}$ overeenkomst vertonen met $\mathrm{L}_{1}$ en $\mathrm{L}_{2}$. Ook $\mathrm{O}_{4}$ en $\mathrm{L}_{4}$ vertonen een zekere overeenstemming. $\mathrm{O}_{4 i}$ en $\mathrm{O}_{7}$ komen niet explicite in de zelfanalyse van de Leider voor, maar zijn elders in zijn beschouwingen te vinden en leveren dus in elk geval geen verschilpunt op.

Wat opvalt is, dat de Leider niet zegt, dat hij de organisatie deel van zijn ., self picture" maakt. Hij blijkt niet te zien, dat hij sommige persoonlijke behoeften tijdens en door de uitoefening van zijn functie bevredigt.

In een volgend hoofdstuk beschrijft Argyris de - ongezonde - afhankelijkheid van de supervisors van hun Leider, zoals die door het gedrag van laatstgenoemde ontstaat. Hij gaat na, hoe denken, maar vooral hoe voelen de supervisors ten aanzien van hun werk, hun collega's, hun eigen ondergeschikten, de Leider en het bedrijf als geheel. 